\title{
Validated Extractive Spectrophotometric Method for Determination of Domperidone in Pharmaceutical Formulations
}

\author{
Jasmin Shah, M. Rasul Jan and Muhammad Tariq Shah \\ Institute of Chemical Sciences, University of Peshawar, KP, Pakistan
}

\begin{abstract}
Simple, precise and sensitive extractive spectrophotometric methods have been developed for the determination of domperidone in pharmaceutical formulations. The new methods involve the formation of colored extractable ion pair complexes of the drug with bromothymol blue (BTB) and bromophenol blue (BPB) in acidic medium. The effects of various parameters like $\mathrm{pH}$, reagent concentration and shaking time were studied. The extracted complexes of domperidone showed maximum absorbance at $410 \mathrm{~nm}$ with BTB and at $415 \mathrm{~nm}$ with BPB dye. The stiochiometry of the reaction between domperidone, BTB and BPB was found to be 1: 4. Domperidone was found to obey Beer's law in the concentration ranges of $0.6-35 \mu \mathrm{g} / \mathrm{ml}, 1-30 \mu \mathrm{g} / \mathrm{ml}$ with BTB and BPB, respectively. The method has been applied successfully for the determination of domperidone in commercial tablets and suspension samples. The results obtained by the proposed methods were validated statistically and compared with the official HPLC method.
\end{abstract}

Key words: Domperidone, bromothymol blue, bromophenol blue, ion pair complexes, spectrophotometry.

\section{Introduction}

Domperidone 5-chloro-1-(1-[3-(2-oxo-2,3-dihydro1H-benzo[d]imidazol-1-yl) propyl] piperidin-4-yl)1Hbenzo[d]imidazol-2(3H)-one] is an antidopaminergic drug, developed by Janssen Pharmaceuticals, and is used orally, rectally or intravenously, generally to suppress nausea and vomiting (Brogden et al., 1982). It has strong affinities for the $\mathrm{D}_{2}$ and $\mathrm{D}_{3}$ dopamine receptors, which are found in the chemoreceptor trigger zone, located just outside the blood brain barrier, which - among others - regulates nausea and vomiting (area postrema on the floor of the fourth ventricle and rhomboid fossa). It has also been used to stimulate lactation (Kobylinska and Kobylinska, 2000).

Literature survey revealed that various methods have been reported for the determination of domperidone in a variety of matrices such as plasma, urine and milk. Some of these assays use ${ }^{14} \mathrm{C}$-labelled drug and are very sensitive but they do not permit the determination of major metabolites of domperidone (Heykants et al., 1981; Michiels et al., 1981). Other assays measure levels of domperidone by radio-immunoassay but antibodies raised in rabbits against domperidone are not commercially available and do not allow for the determination of domperidone metabolites (Heykants et al., 181; Michiels et al., 1981; Huang et al., 1986). UV spectrophotometry and HPLC methods have also been used for the determination of domperidone by expensive and time consuming derivatization procedure (Kobylinska and Kobylinska, 2000; Yamamoto et al., 1998; Zavitsanos et al., 1999; Saleem et al., 2002; Saleem et al., 2003; Hang et al., 2008; Sherje et al., 2008; Jet et al., 2008; Sabnis et al., 2008; Reddy, 2009; Kakde et al., 2009; Patel et al., 2009; Gandhi et al., 2009; Prasad et al., 2009).

Thus, there is always need for development of improved analytical methodology for the determination of any drugs, including demperidove to monitor the quality of the pharmaceutical products. Spectrophotometry is widely used in all over the world in chemical and biochemical laboratories and famous for its speed of analysis, simplicity, accuracy and inexpensive instruments. Hence, it is an important alternative to other analytical techniques with clear advantages in terms of cost of analysis. To the best of our knowledge there is no report available in literature for the extractive spectrophotometric method for the assay of domperidone.

Our present study aims to develop new simple extractive spectrophotometric methods for the determination of domperidone in pharmaceutical 
formulations. These methods are based on the formation of ion pair complexes of domperidone with acidic dyes bromothymol blue (BTB) and bromophenol blue (BPB) in acidic medium followed by their extraction with chloroform. The proposed methods are rapid, simple, precise and accurate for quantification of domperidone in commercial formulations.

\section{Materials and Methods}

Instruments: UV/Vis Spectrophotometer (Optima SP3000 plus, Tokyo, Japan), with matched $1 \mathrm{~cm}$ quartz cells was used for all spectrophotometric measurements. $\mathrm{pH}$ meter (Model-7020 Kent Industrial Measurement Limited, Electronic Instrument LTD, Chertsey Survey England) with combined glass electrode was used during this work.

Reagents: The following analytical grade chemicals were obtained from the indicated companies and utilized as received without any further purification; bromothymol blue (BTB), bromophenol blue (BPB), acetic acid, sodium acetate, boric acid, phosphoric acid, chloroform and methanol were procured from Merck, Darmstadt, Germany. Standard reference domperidone was supplied by Libra Pharmaceutical Industries Private Limited, Hayat, Abad, Peshawar, Pakistan.

Preparation of stock solutions: Stock solution of domperidone $(1000 \mu \mathrm{g} / \mathrm{ml})$ was prepared by dissolving $0.05 \mathrm{~g}$ of domperidone in $20 \mathrm{ml}$ analytical grade methanol and the solution was then diluted to $50 \mathrm{ml}$ with methanol. Working standard $(100 \mu \mathrm{g} / \mathrm{ml})$ of domperidone solution was prepared from stock solution by dilution method.

BTB $(0.1 \%)$ and BPB $(0.1 \%)$ solution were prepared by dissolving appropriate amount of each dye in $30 \mathrm{ml}$ of methanol and diluting up to $100 \mathrm{ml}$ with distilled water in a $100 \mathrm{ml}$ volumetric flask. Acetate buffer solution was used for preparation of $\mathrm{pH} 4$ and Briton Robinson buffer solution was used as $\mathrm{pH} 3$ buffer solutions. The $\mathrm{pH}$ meter was used for checking and adjusting $\mathrm{pH}$ of each buffer solution.

General procedure: A series of experiments were conducted by taking an aliquot of the standard domperidone solution in the concentration range of 0.2$10.0 \mu \mathrm{g} / \mathrm{ml}$ for BTB and BPB and were transferred to a series of $250 \mathrm{ml}$ separating funnels. Then $8.0 \mathrm{ml}$ acetate buffer solution $(\mathrm{pH} \mathrm{4})$ for BTB and $5.0 \mathrm{ml}$ of Britton Robinson buffer solution $(\mathrm{pH} 3)$ for BPB methods were added in each separating funnel; followed by the addition of $6.0 \mathrm{ml}$ of $0.1 \%$ BTB and $8.0 \mathrm{ml}$ of $0.1 \%$ BPB solutions in specified separating funnels. To each of the solution $10.0 \mathrm{ml}$ of chloroform was added and shaken for 30 seconds, and allowed to stand for clear separation of two phases. The resulting yellow ion pair complex in chloroform was separated and the absorbance was measured at $410 \mathrm{~nm}$ for BTB dye and at $415 \mathrm{~nm}$ for BPB dye against a reagent blank prepared in an identical fashion without addition of drug. A calibration graph of absorbance versus the concentration of domperidone was plotted.

Analysis of tablets: Seven tablets were finely powdered. An amount equivalent to $0.05 \mathrm{~g}$ of domperidone was weighed accurately and transferred into a volumetric flask. The powder was completely disintegrated in methanol using a mechanical stirrer, filtered and diluted upto $50.0 \mathrm{ml}$ with methanol. An aliquot was analyzed by the proposed procedure.

\section{Results and Discussion}

For maximum complex formation of domperidone with $\mathrm{BTB}$ and $\mathrm{BPB}$, effects of different variables on the ion pair complex reactions were studied.

Optimization of various parameters: The effects of different experimental variables on the stability of the ion pair complexes of domperidone with BTB and BPB were investigated and optimized. These factors including $\mathrm{pH}$, concentration of reagents, extraction time and organic solvents for extraction were studied for optimum analytical signals.

Domperidone forms yellow colored ion pair complexes in acidic buffer with BTB and BPB. The complexes showed absorption maxima at $410 \mathrm{~nm}$ and 415 $\mathrm{nm}$ with BTB and BPB, respectively (Figure 1a and 1b). Under the optimized experimental conditions the reagent blank showed negligible absorbance due to the presence of dye and buffer which are non-extractable in ionic form in non polar solvent (chloroform).

Domperidone contains amine groups which are protonated in acidic media, while sulphonic group present in BTB and BPB undergoes dissociation in the $\mathrm{pH}$ range of 2.0-5.0. The protonated domperidone forms ion pair complex with the anionic forms of BTB and BPB, which are quantitatively extracted into chloroform. The proposed 
reaction mechanism for ion pair complex of domperidone with BTB is given in Scheme I and with BPB in Scheme II.

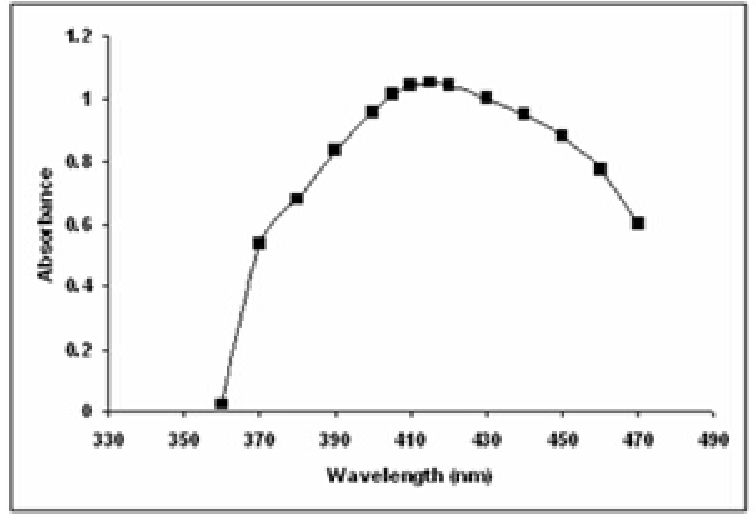

Figure 1a. Absorption spectra of domperidone ion pair complex (domperidone-BTB).

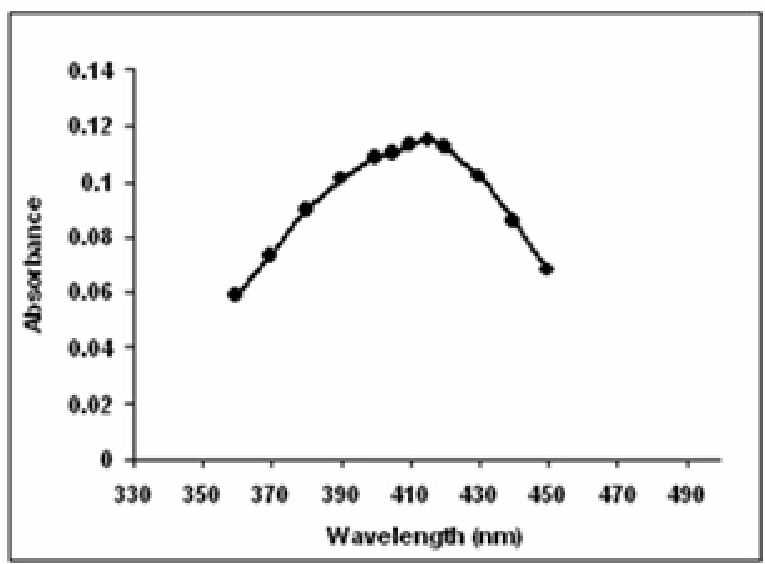

Figure 1b. Absorption spectra of domperidone ion pair complex (domperidone-BPBP).

Effects of $\mathrm{pH}$ : $\mathrm{pH}$ plays an important role in the formation of ion pair complexes. The effect of $\mathrm{pH}$ on the formation of ion pair complexes of domperidone with BTB and BPB was investigated using acetate and Britton Robinson buffer. The results are shown in Figure 2. It has been observed that maximum absorbances of complexes were found with $\mathrm{BTB}$ at $\mathrm{pH} 4$ using acetate buffer and $\mathrm{BPB}$ at $\mathrm{pH} 3$ using Briton Robinson buffer.

Effects of solvents: Solvents like dichloromethane, chloroform, ether, benzene and ethyl acetate were studied for the formation and extraction of ion pair complexes. The results revealed chloroform as the most suitable solvent for the extraction of yellow colored ion pair complexes. Therefore, further extraction was carried out with chloroform.
Effect of dye concentration: The effect of BTB and BPB concentration was studied by adding different volumes of $0.1 \%$ solution of BTB and BPB to a constant concentration of domperidone (Figure 3).

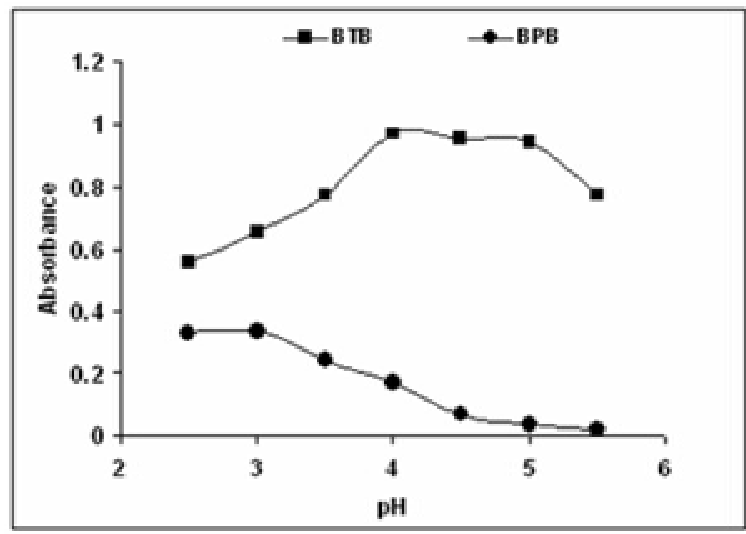

Figure 2. Effect of $\mathrm{pH}$ on ion pair complexes of domperidone.

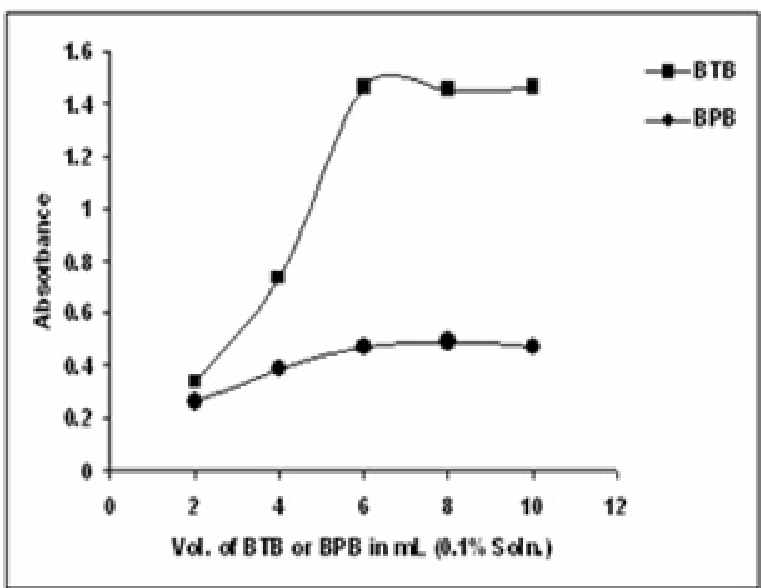

Figure 3. Effect of dye concentration on ion pair complex.

Maximum absorbance of ion-association complex was found at $6.0 \mathrm{~mL}$ of $0.1 \%$ solution of BTB and $8 \mathrm{~mL}$ of $0.1 \%$ solution of BPB, beyond which absorbance was found to remain constant.

Effect of shaking time and stability of complex: To determine the most efficient time for ion pair complex formation and extraction into chloroform, shaking time was studied from 0.5 to 3.0 minutes. As a result 0.5 minute shaking time was found be suitable. The ion pair complexes are also observed to be quite stable at room temperature with BTB and BPB.

Stoichiometry: The stoichiometric ratio of the ion pair complexes were studied by mole ratio method. A 
comparable solution of domperidone with BTB and BPB reagents were used. For each dye, series of solutions were prepared with constant volume of domperidone and variable volume of dye. The rest of the procedure was the same as mentioned in general procedure. The mole ratio method indicated 1:4 ratio of domperidone with BTB and BPB (Figure 4).

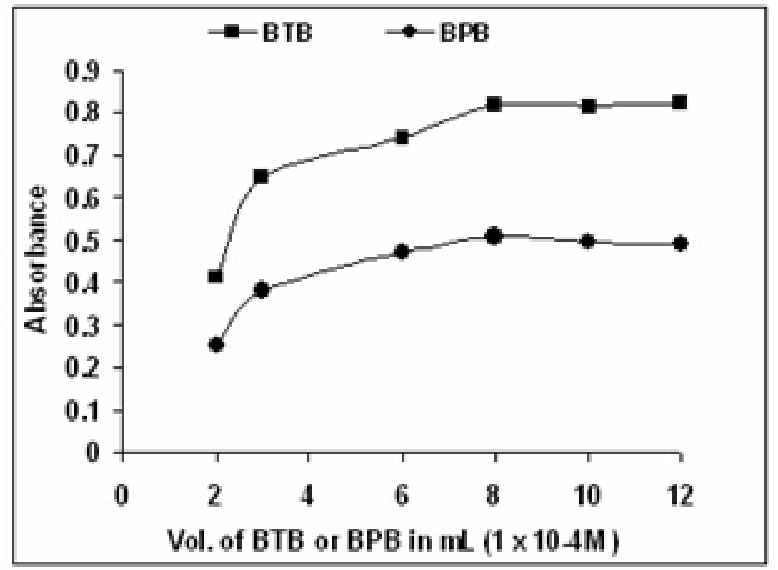

Figure 4. Mole ratio study of drug-dye system (DomperidoneBTB and domperidone-BPB ion pair complexes).

Analytical figures of merit: At the optimized conditions, calibration graphs were drawn and the molar absorptivity, linear range and correlation coefficient for domperidone were calculated. Beer's law range of concentration from $0.6-35 \mu \mathrm{g} / \mathrm{ml}$ with BTB and 1.0-30 $\mu \mathrm{g} / \mathrm{ml}$ with BPB was found with good correlation coefficient $\left(\mathrm{r}^{2}\right)$ value of 0.9931 for BTB and 0.9996 for
BPB method. Intercept value calculated by least square method was negligible. The limit of detection (LOD) and limit of quantification (LOQ) were calculated according to the ICH guidelines (ICH Topic Q2B 1995). The LOD $(3.3 \mathrm{~s} / \mathrm{b})$ was determined by establishing the minimum level at which domperidone can be detected reliably and it was found to be 0.201 and $0.05 \mu \mathrm{g} / \mathrm{ml}$ with BTB and BPB. The LOQ $(10 \mathrm{~s} / \mathrm{b})$ was calculated by establishing the lowest concentration of domperidone that can be measured with acceptable precision and accuracy. Domperidone can be determined quantitatively under these conditions at a concentration of $0.67 \mu \mathrm{g} / \mathrm{ml}$ with BTB and $0.169 \mu \mathrm{g} / \mathrm{ml}$ with BPB. The results are given in Table 1.

Selectivity: The effects of various excipients that often used in different pharmaceutical preparations were studied for selectivity of the proposed method. An attractive feature of extractive spectrophotometric method is its relative freedom from interferences by the tablet diluents and excipients like talc, starch, sucrose, lactose, acetate, citrate and phosphate at the levels found in dosage forms.

Precision and accuracy: Accuracy and precision of the two methods were determined by analyzing three different concentrations in three replicates of each commercial formulation (Table 2). The precision results showed that the proposed methods have good reproducibility. The percent recoveries with RSD were found to be in the range of $98.0-103.50 \% \pm 1.65-4.28 \%$.

Table 1. Analytical characteristics of the proposed method for determination of domperidone using BTB and BPB.

\begin{tabular}{lcc}
\hline Parameter & \multicolumn{2}{c}{ Values } \\
\cline { 2 - 3 } & BTB & BPB \\
\hline mHax $(\mathrm{nm})$ & 415 & 315 \\
Extracting solvent & 4 & Chloroform \\
Complex stability $(\mathrm{h})$ & Chloroform & 24 \\
Molar ratio (Domperidone: BTB or BPB & 24 & $1: 4$ \\
$\mathrm{~K}_{\mathrm{f}}$ & $1: 4$ & $1.23 \times 10^{18}$ \\
Beer's law limit $(\mu \mathrm{g} / \mathrm{ml})$ & $1.8 \times 10^{18}$ & $1-30$ \\
Correlation coefficient $\left(\mathrm{r}^{2}\right)$ & $0.6-35$ & 0.9931 \\
Slope & 0.9996 & 0.0300 \\
Intercept & 0.0461 & 0.0456 \\
RSD $\%$ & 0.1562 & 2.099 \\
Limit of detection $(\mu \mathrm{g} / \mathrm{ml})$ & $3.53 \%$ & 0.5 \\
Limit of quantification $(\mu \mathrm{g} / \mathrm{ml})$ & 0.2 & 0.79 \\
Molar zbsorbtivity $(\mathrm{L} / \mathrm{mol} / \mathrm{cm})$ & 0.67 & $1.04 \times 10^{4}$ \\
\hline
\end{tabular}


Table 2. Evaluation of precision and accuracy of the proposed methods for domperidone determination in pharmaceutical formulations $(n=4)$.

\begin{tabular}{lcccccc}
\hline $\begin{array}{l}\text { Pharmaceutical } \\
\text { formulation }\end{array}$ & \multicolumn{3}{c}{ BTB } & \multicolumn{3}{c}{ BPB } \\
\cline { 2 - 6 } & $\begin{array}{c}\text { Amount taken } \\
(\mu \mathrm{g} / \mathrm{ml})\end{array}$ & $\begin{array}{c}\text { Amount found } \\
(\mu \mathrm{g} / \mathrm{ml})\end{array}$ & $\begin{array}{c}\text { \%Recovery } \\
\pm \mathrm{RSD}\end{array}$ & $\begin{array}{c}\text { Amount taken } \\
(\mu \mathrm{g} \mathrm{ml})\end{array}$ & $\begin{array}{c}\text { Amount found } \\
(\mu \mathrm{g} / \mathrm{ml})\end{array}$ & $\begin{array}{c}\text { \% Recovery } \\
\text { RSD }\end{array}$ \\
\hline Motilium tablet & 4.0 & 4.15 & $103.6 \pm 1.2$ & 2.0 & 2.0 & $100.0 \pm 2.64$ \\
& 6.0 & 6.14 & $103.5 \pm 2.2$ & 4.0 & 4.01 & $100.03 \pm 2.63$ \\
& 8.0 & 8.16 & $104.0 \pm 2.5$ & 6.0 & 6.4 & $101.5 \pm 1.83$ \\
Emiset tablet & 2.0 & 1.97 & $98.8 \pm 2.60$ & 2.0 & 4.98 & $99.0 \pm 2.48$ \\
& 4.0 & 4.08 & $102.0 \pm 2.40$ & 4.0 & 6.0 & $100.0 \pm 1.74$ \\
Motilium suspension & 6.0 & 5.86 & $97.4 \pm 2.67$ & 6.0 & $103.0 \pm 2.27$ \\
& 2.0 & 1.91 & $95.8 \pm 2.48$ & 2.0 & 4.91 & $95.6 \pm 1.65$ \\
& 4.0 & 3.99 & $99.9 \pm 2.72$ & 4.0 & 3.81 & $95.3 \pm 1.99$ \\
& 6.0 & 5.91 & $98.5 \pm 2.59$ & 6.0 & 5.97 & $99.5 \pm 2.52$ \\
\hline
\end{tabular}

Each result is the average of separate triplicate analysis.

Table 3. Evaluation of recovery test of domperidone in commercial formulations by the proposed method. (Standard addition method) $(n=5)$.

\begin{tabular}{|c|c|c|c|c|c|}
\hline \multirow{2}{*}{$\begin{array}{l}\text { Pharmaceutical } \\
\text { preparation }\end{array}$} & \multirow{2}{*}{$\begin{array}{l}\text { Amount added } \\
(\mu \mathrm{g} / \mathrm{ml})\end{array}$} & \multicolumn{2}{|c|}{ BTB } & \multicolumn{2}{|c|}{ BPB } \\
\hline & & $\begin{array}{c}\text { Amount found } \\
(\mu \mathrm{g} / \mathrm{ml})\end{array}$ & $\begin{array}{c}\% \text { Recovery } \\
\pm \text { RSD }\end{array}$ & $\begin{array}{c}\text { Amount found } \\
(\mu \mathrm{g} / \mathrm{ml})\end{array}$ & $\begin{array}{c}\% \text { Recovery } \\
\pm \text { RSD }\end{array}$ \\
\hline \multirow[t]{3}{*}{ Motilium tablet } & 2.0 & 2.02 & $101.0 \pm 2.43$ & 2.07 & $103.5 \pm 1.26$ \\
\hline & 4.0 & 4.05 & $101.2 \pm 2.26$ & 4.07 & $101.7 \pm 2.32$ \\
\hline & 6.0 & 6.05 & $100.8 \pm 2.40$ & 6.03 & $102.3 \pm 1.86$ \\
\hline \multirow[t]{3}{*}{ Emist tablet } & 2.0 & 1.9 & $95.0 \pm 2.54$ & 1.97 & $98.5 \pm 2.516$ \\
\hline & 4.0 & 3.85 & $96.2 \pm 2.37$ & 3.95 & $99.9 \pm 2.29$ \\
\hline & 6.0 & 5.86 & $98.25 \pm 1.9$ & 5.95 & $99.16 \pm 2.16$ \\
\hline \multirow[t]{3}{*}{ Motilium suspension } & 2.0 & 1.98 & $99.0 \pm 1.75$ & 1.97 & $98.5 \pm 1.77$ \\
\hline & 4.0 & 3.93 & $98.2 \pm 2.35$ & 3.99 & $99.74 \pm 2.75$ \\
\hline & 6.0 & 5.92 & $98.7 \pm 1.38$ & 6.03 & $100.5 \pm 1.28$ \\
\hline
\end{tabular}

Each result is the average of separate triplicate analysis.

Table 4. Determination of domperidone in commercial formulation and statistical comparison with reference method (n=4).

\begin{tabular}{|c|c|c|c|c|}
\hline \multirow[t]{2}{*}{ Drug } & \multicolumn{4}{|c|}{ Amount found } \\
\hline & $\begin{array}{l}\text { Labeled amount } \\
\mathrm{mg} / \mathrm{tab}\end{array}$ & Proposed method BTB & Proposed method BPB & $\begin{array}{c}\text { Reference method } \\
{[15]}\end{array}$ \\
\hline Motilium tablets & 10 & $\begin{array}{c}10.35 \pm 2.45 \\
\text { F-test }=1.133(3.4) \\
\text { t-test }=1.162(2.303)\end{array}$ & $\begin{array}{c}10.06 \pm 2.61 \\
\text { F-test } 0.449(3.4) \\
\text { t-test }=1.168(2.303)\end{array}$ & $9.97 \pm 2.35$ \\
\hline Emist tablets & 10 & $\begin{array}{c}9.94 \pm 1.88 \\
\text { F-test } 2.29(3.4) \\
\text { t-test }=1.162(2.303)\end{array}$ & $\begin{array}{c}10.07 \pm 2.46 \\
\text { F-test }=2.52(3.4) \\
\text { t-test }=0.895(2.303)\end{array}$ & $9.9 \pm 2.79$ \\
\hline Motilium suspension & $1 \mathrm{mg} / \mathrm{ml}$ & $\begin{array}{c}0.98 \pm 2.68 \mathrm{mg} / \mathrm{ml} \\
\text { F-tes } \mathrm{t}=1.156(3.4) \\
\text { t-test }=0.487(2.303)\end{array}$ & $\begin{array}{c}0.968 \pm 2.77 \mathrm{mg} / \mathrm{ml} \\
\text { F-test }=1.633(3.4) \\
\text { t-test }=0.895(2.303)\end{array}$ & $0.995 \pm 2.97$ \\
\hline
\end{tabular}

Accuracy of the methods was evaluated by standard addition method. Known quantities of pure domperidone were added to a known amount of pre-analyzed formulations and the mixtures were analyzed by the proposed method. The total amount of domperidone was then determined and the amount of the recovered 
domperidone was calculated by difference. The percent recoveries for commercial formulations were in the range of $93.3 \pm 2.09-103.0 \pm 2.38 \%$ and $93.3 \pm 1.23-103.5 \pm$ $1.26 \%$ for BPB and BTB, respectively (Table 3 ).

Application of the method: The proposed methods were successfully applied to the determination of domperidone in commercial formulations. These results of the proposed methods were compared to the published HPLC method (Sabnis et al., 2008) and were found in good agreement with the label values (Table 4). The results were compared statistically with the reference HPLC method for precision and accuracy using student's t-test and variance ratio F-test at $95 \%$ confidence level. The calculated t-values and F-values are lower than the theoretical values showing that the proposed method and reference methods are statistically equivalent in terms of precision and accuracy.

\section{Conclusion}

Extractive spectrophotometric methods have been developed for the determination of domperidone in pharmaceutical formulations. The methods were based on the formation of ion pair complexes of domperidone with acidic dyes bromothymol blue (BTB) and bromophenol blue (BPB) in acidic buffer followed by their extraction in chloroform. These methods have been statistically evaluated were found to be precise. The methods depend on the use of simple chemicals and the sensitivity are comparable to that achieved by sophisticated and expensive techniques like HPLC. Therefore, these methods could be used as alternative for rapid and routine determination of bulk samples and tablets as a part of industrial quality control.

\section{References}

Brogden, R.N., Carmine, A.A., Heel, R.C., Speight, T.M. and Avery, G.S. 1982. Domperidone: a review of its pharmacological activity, pharmacokinetics and therapeutic efficacy in the symptomatic treatment of chronic dyspepsia and as an antiemetic. Drugs 24, 360-400.

Gandhi, S.V., Khan, S.I., Jadhav, R.T., Jadhav, S.S. and Jadhav, G.A. 2009. HP-TLC determination of rabeprazole sodium and domperidone in combined dosage form, J. A.O.A.C. Int. 92, 1064-1067.
Hang, X.D., Gang, L.H., Hong, Y., Bo, J., Quan, Z., Miao, Z.Z. and Rang, R.Z. 2008. Quantitative determination of domperidone in human plasma by ultra performance liquid chromatography with electrospray ionization tandem mass spectrometry. Biomed. Chromatogr. B, 22, 433-40.

Heykants, J., Knaeps, A., Meuldermans, W. and Michiels, M. 1981. On the pharmacokinetics of domperidone in animals and man I. Plasma levels of domperidone in rats and dogs. Age related absorption and passage through the blood brain barrier in rats. Eur. J. Drug Metab. Pharmacokinet. 6, $27-$ 36.

Heykants, J., Hendriks, R., Meuldermans, W., Michiels, M., Scheygrond, H. and Reyntjens, H. 1981. On the pharmacokinetics of domperidone in animals and man IV. The pharmacokinetics of intravenous domperidone and its bioavailability in man following intramuscular, oral and rectal administration. Eur. J. Drug Metab. Pharmacokinet. 6, 61-70.

Huang, Y.C., Colaizzi, J.L., Bierman, R.H., Woestenborghs R. and Heykants J.J. 1986. Pharmokinetic and dose proportionality of domperidone in healthy volunteers. $J$. Clin. Pharmacol. 26, 628-633.

International Conference on Harmonization of Technical Requirements for Registration of Pharmaceuticals for Human Use, (1996). ICH Topic Q 2 B, Validation of analysis procedure: Methodology (CPMP/ICH/281/1995), Step 4, Consensus Guidelines, London, UK.

Jet, C., De Steene, V. and Lambert, W.E. 2008. Validation of solid phase extraction and LC- electrospray tandem mass spectrometric method for determination of nine basic pharmaceuticals in waste water and surface water samples. J. Chromaogr. A 1182, 153-160.

Kakde, R.B., Gedam, S.N., Chaudhry, N.K., Barsagade, A.G., Kale, D.L. and Kasture, A.V. 2009. Three wavelength spectrophotmetric method for simultaneous estimation of pantoprazole and domperidone in pharmaceutical preparations. Int. J. Pharm. Tech. Res. 1, 386-389.

Kobylinska, M. and Kobylinska, K. 2000. High-performance liquid chromatographic analysis for the determination of domperidone in human plasma. J. Chromatogr. B. 744, 207-212.

Michiels, M., Hendriks, R. and Heykants, J. 1981. On the pharmacokinetics of domperidone in animals and man II. Tissue distribution, placental and milk transfer of domperidone in the Wistar rat. Eur. J. Drug Metab. Pharmacokinet. 6, 37-48.

Patel, B., Dedania, Z., Dedania, R., Ramolia, C., Sagar, G.V. and Mehta, R.S. 2009. Simultaneous estimation of lansoprazole and domperidone in combine dosage form by RP-HPLC. Asian J. Res. Chem. 2, 210-212. 
Prasad, Y.R., Rajasekar, K.K., Shankarananth, V., Yaminikrishna, H.V., Saikumar, S. and Raghavreddy, P.V. 2009. Spectrophotometric method for estimation of domperidone in bulk and pharmaceutical formulations. $J$. Pharm. Res. 2, 1593-1594.

Reddy, B.P. 2009. Simultaneous HPLC estimation of pantoprazole and domperidone from tablets. Int. J. Chem. Tech. Res. 1, 275-277.

Sabnis, S.S., Dnvandev, N., Jadhav, V.Y. and Gandhi, S.V. 2008. RP-HPLC method for simultaneous determination of rabeprazole and domperidone in combined tablet dosage form. J. A.O.A.C. Int. 91, 344-348.

Saleem, M.Y., El-Bardicy, M.G., El-Tarras, M.F. and ElZanfallay, E.S. 1981. Simultaneous determinaton of domperidone maleate and cinnarizine in a binary mixture using derivative ratio spectrometry and classical least square calibration. J. Pharm. Biomed. Anal. 30, 21-33.
Saleem, M.Y., El-Zanfaly, E.S., El-Tarras, M.F. and El-Bardicy, M. 2003. Simultaneous determination of domperidone and cinnarizine in a binary mixture using derivative spectrophotometry, partial least squares and principle component regression calibration, Anal. Bioanal. Chem. 375, 211-216.

Sherje, A.P., Kasture, A.V., Gujar, K.N. and Yeole, P.G. 2008. Simultaneous spectrophotometric determination of lansoprazole and domperidone in capsule dosage form. Indian J. Pharm. Sci. 70, 102-105.

Yamamoto, K., Hagino, M., Kotaki, H. and Iga, T. 1998. Quantitative determination of domperidone in rat plasma by HPLC with fluorescence detection. J. Chromatogr. B. 720, 251-255.

Zavitsanos, A.P., Macdonald, C., Basso, E. and Gopaul, D. 1999. Determination of domperidone in human serum and human breast milk by HPLC-electrospray mass spectrometry. $J$. Chromatogr. B. 730, 9-24. 